\title{
DOES SOCIAL MEDIA IMPROVE THE WELFARE OF TOURISM BUSINESSES?
}

\author{
Hadi Sasana \\ hadisasana@live.undip.ac.id \\ Universitas Diponegoro \\ J1. Prof. Sudarto No.13, Tembalang, Semarang, Jawa Tengah 50275 \\ Ivo Novitaningtyas \\ Jihad Lukis Panjawa \\ Universitas Tidar \\ Jl. Kapten Suparman 39, Potrobangsan, Magelang Utara, Jawa Tengah 56116
}

received: 10/12/19; revised: 28/5/20; approved: 29/6/20

\begin{abstract}
This research aims to analyze the factors that affect welfare of tourism business owners, especially the role of social media. This research uses primary data and cluster sampling method. Data was analyzed use multiple linear regression. The results show that social media has positive effect toward income of tourism business, but not significant. Moreover, income from tourism business has positive significant effect toward household consumption. Development of tourism gives benefits for local communities such as increase tourism business and increase their income. Therefore, tourism business should improve the ability of using social media as promotional tools to increase their welfare.
\end{abstract}

Keywords: economic; tourism business; social media; household consumption; welfare

\section{INTRODUCTION}

Tourism development is a part of national development. Indonesia is one of the countries that has tourism potential. This country has tourism resources such as natural tourist attraction (beach, undersea scenery, plateau, lake, mountain, and agrotourism), cultural tourist attraction (museum, temple, local culture, traditional ceremony), and also special interest tourist attraction (MICE, culinary, sports tourism). These potentials need to be developing. The previous study stated that tourism development has positive impact on the regional economy (Syah \& Rustanto, 2018). Based on that, the development of tourism is expected to have positive impacts on Indonesia.

Dieng Plateau area is one of the tourism destinations in Indonesia. Moreover, this destination is known as one of the main tourism destinations in Central Java Province. Dieng Plateau has a complete package of tourist attractions. This site has natural tourist attractions such as hills and crater. Then, it has some of the temples as the cultural tourist attractions. This destination also has local noodles called Mie Ongklok as the culinary tourism. This tourism destination offers complete $3 \mathrm{~S}$ something to see, something to do, and something to buy for tourists. According to Yoo, et. al. (2018), the motivations of tourists to visit tourism destinations are scenery, exotic experience, culture, relaxation, self-actualization, physical refreshment, and pleasureseeking. Therefore, Dieng Plateau has potential to be visited by many tourists.

Nowadays, Industrial Revolution 4.0 has an impact on all sectors including tourism. Industry 4.0 also has a role to encourage sustainable business performance (Haseeb et al., 2019). The implementation of e-marketing via social media in tourism is one of the examples (Widjaja et al., 2016). Social media has been recognized as one of the tools for marketing in tourism. Furthermore, social media and its activities enable stakeholders in the tourism industry to have an appropriate insight in the world of tourists, and also to create relationship with the tourists (Zivkovic et al., 2014). Other than that, social media also gives benefits like reducing expenditure on marketing such as promotion and advertising via offline media (Gururaja, 2015). Based on that, social media is an important variable that has an impact on tourism development.

Social media as a promotion tool becomes the strategy to develop the tourism business (Rusliati et al., 2018). The success of promotion through social media can increase the number of visitors or tourists. Results from previous research said that tourist's travel decision are influences 
by activities in social media such as image posting, commenting, and reviewing (Karim, 2018). Thus, will increase the income of the local communities who did the tourism business. Based on that, local communities whose did tourism business as the user of social media should be smart to use this media as the marketing tools. They should have ability to use social media in order to promote their tourism business.

Furthermore, social media has been proven to have an impact on tourism industry growth. The previous study stated that social media has a role as a promotion tool for tourism entrepreneurs in Bangladesh (Karim, 2018). The usage of social media as a tool to promote tourism objects will increase the number of tourists. As a result, tourist visits will increase tourism destination revenue and it can help develop tourism industry. This previous research reveals that the contribution of tourism industry will bring economic benefits for developing countries.

On the other hand, the findings from previous research stated that social media has both positive and negative impacts on the tourism sector (Sahin \& Sengun, 2015). Social media shares not only positive information but also negative. Information on social media such as comments, pictures, and reviews will affect the users. It will also affect tourists to decide their travel or tour plans. Furthermore, tourism decisions of the young generation have been strongly affected by reviews about a destination from social media (Sahin \& Sengun, 2015). Therefore, tourism entrepreneurs should be able to handle bad reviews on social media and maintain a good image for their tourism business.

Based on the previous findings, there is a research gap about the impact of social media on the tourism industry. Some researchers said the important role of social media on tourism and its economy's impact on tourism entrepreneurs. Other research reveals the negative impact of social media on the tourism business. This study attempts to analyze the impact of social media and other factors that influence the tourism business's welfare.

\section{METHODS}

This research implements a quantitative research approach. Primary data were obtained from the questionnaire as the data collection method. The data collection period was conducted from May to August 2019. The sampling method used in this research is the cluster sampling method. The respondents are local communities who have tourism businesses in Dieng Plateau (food stalls owner, souvenir shop owner, restaurant owner, tour guide, and homestay owner). The questionnaire was developed to test the hypothesis with 118 respondents as samples. This research proposes 2 models, the first model contains 5 independent variables, the variables are age (AG), level of education (ED), working time (WT), number of tourists (TR), social media (SM) and 1 dependent variable income from tourism business of local communities (INC). The first model uses to examine the impact of social media and other demographic factors on tourism business income. The second model contains tourism business income (INC) as the independent variable and household consumption $(\mathrm{CO})$ as the dependent variable. This model uses to test the effect of tourism business income on household consumption. Primary data obtained from the questionnaire were analyzed by multiple linear regressions based on the Ordinary Least Square (OLS) method.

This research proposes equation model as follow: First model:

$\mathrm{INC}=\alpha+\beta 1 \mathrm{AG}+\beta 2 \mathrm{ED}+\beta 3 \mathrm{WT}+\beta 4 \mathrm{TR}+\beta 5 \mathrm{SM}$ $+\varepsilon$

Second model:

$\mathrm{CO}=\alpha+\beta 1 \mathrm{INC}+\varepsilon$

\section{RESULTS}

As mentioned earlier, respondents in this research are 118 local peoples who have a tourism business in Dieng Plateau. Table 1 illustrates that the ratio of female respondents is higher than male respondents which is $65 \%$ and $35 \%$ respectively. Percentage for age is dominated by $38-47$ years old $(30 \%)$, while the rest are 48-57 years old (22\%), 18-27 years old (20\%), 28-37 years old $(16 \%), 58-67$ years old $(10 \%), 68-77$ years old (1\%), and 78-87 years old (1\%). The type of tourism businesses are various, consist of food stalls (59\%), souvenir shop (30\%), restaurant (1\%), tour guide (7 $\%$ ), and homestay (4\%). Based on the level of education, $37 \%$ respondents are graduated from Junior High School, and the rest are other level of education such as Elementary School (29\%), Senior High School (26 $\%$ ), College (only $7 \%$ ), without education background $(2 \%)$. Furthermore, some of the respondents already have social media. The majority of respondents have 3 kinds of social media. The result shows that $53 \%$ of respondents have 3 social media, while the rest have 1 social media (25\%), 2 social media (14\%), and 4 social media (only $8 \%$ ).

Table 2 shows that the average of working times from respondents in a month is 227 hours, in a week is 57 hours, and 8 hours per day to work for their tourism business. The average of tourists who are visiting their tourism business in a month is 192 tourists, then 48 tourists per week, and 7 tourists per day. The highest number of tourists achieved every weekend. The number of tourists on a weekday is less than the number of tourists at the weekend. Beside of that, the average of their income in a month is IDR 3.999.153, while the average of their household consumption in a month is IDR 2.540.720. 
Based on regression result shows in Table 3, the estimation results explained as follow:

$$
\begin{aligned}
& \mathrm{INC}=-2706781.995+48386.977 \mathrm{AG}+126563.564 \mathrm{ED} \\
& +15795.775 \mathrm{WT}+1983.450 \mathrm{TR}+369516.24 \mathrm{SM} \\
& +\mathrm{v} \varepsilon
\end{aligned}
$$

The regression estimation result shows a positive and significant effect between ages toward tourism business income. For the relationship between the level of education and tourism business income, the estimation result shows that the level of education has a positive and significant effect. Result of regression estimation also proves that working time has a positive and significant effect on tourism business income. For the fourth variable, the regression estimation shows that number of tourists has a positive impact on tourism business income but not significant. Moreover, the result also shows that social media has a positive effect on tourism business income, but not significant.

Based on the regression result shows in Table 4, the estimation results explained as follow:

$$
\mathrm{CON}=978372.419+0.391 \mathrm{INC}+\varepsilon
$$

The result shows that variable tourism business income has a positive and significant effect on variable household consumption.

\section{DISCUSSION}

Income is an important component to improve the prosperity level. The amount of someone's income depends on their job. Income defines as total revenue from the sales of the product (goods and services) which is received by someone or household for a certain period (Mankiw, 2015). Income is affecting by some factors of demographic characteristics such as age and level of education. Moreover, other factors such as working time and the number of consumers also have an impact on income.

In the relationship between age and income, previous researcher explained that as people age and gain work experience will increase their income (Luong \& Hebbert, 2009). Thus, as well as entrepreneurs in tourism business, the more experienced people because of getting older the better they can manage their tourism business. Based on that, if the tourism business managed by well-experienced people it can improve the income. Regression estimation result shows a positive and significant effect between ages toward tourism business income. The result shows that the value of the positive effect is 48386.977 . The majority of respondents are $38-47$ years old. Based on that, the range of age shows that the majority of respondents are in productive category to be employees or entrepreneurs. Regression coefficient value is 48386.977 proves that every 1 year of increasing age will increase income IDR 48.356.977. Commonly, someone who has a productive age will receive higher income compared with an unproductive age. Previous research said that someone will receive the highest income when they reach 40-60 years old (Chetty, 2016). Other research explained that people in a range of productive age is happier than unproductive age because they receive higher income (Hsieh, 2011). This result supports previous research because age has a positive and significant effect on income. Based on that, the more aging local people in Dieng Plateau with well experienced will increase their income for tourism business.

Besides age, the level of education also considers as the factor that influences income. Level of education is proved that has a positive impact on employee's carrier because education determines their position in the labor market (Turcinkova \& Stavkova, 2012). Thus, as well as entrepreneurs in tourism business also need education. The well-educated people the better they can manage their tourism business (Agustina, 2019). Based on that, if the tourism business managed by well-educated people it can improve the income. Estimation result shows that level of education has a positive and significant effect on income. The respondents are dominating by people graduated from Junior High School, while the rest are graduated from Elementary School and Senior High School. Other than that, there are 7 respondents who are graduated from University and 2 respondents have no education background. Previous research proved that people who have same level of education and same occupation will receive the same income, on the other hand when they have a higher level of education they will receive the higher income (Justus, Kawamura, \& Kassouf, 2015). The other researcher said that the level of income will following the level of education (Figueiredo \& Nakabashi, 2016). Level of education determines employee position in the company or organization (Turcinkova \& Stavkova, 2012). An employee that has higher level of education will get opportunities to have higher position in the company or organization. Result from this research supports the previous research. Thus, well-educated people will have the skill to develop their tourism business.

Besides the demographic characteristic, working time is considering as the determinant of income. Working time is an important part of the employee because it is will affect the employee's performance. Working time defines as the amount of time which is needs by someone to do some work (Cette et al., 2011). A proportional working time will produce good labor productivity, so it can improve the company's income (Cette et al., 2011). From the statement before, if the local people in tourism business work with the proportional time they will have better performance. If they have better performance it is expected to increase their income. Result of regression estimation proves 
that working time has a positive and significant effect on income. This result supports previous research which is also proved that people will have higher income if they can maximize their working time (Monte, 2017). Other than that, result from previous research said that people prefer to add their working time because they will get more overtime wages (Strazdins, 2017). Based on that, if local people who have tourism businesses can manage their working time, it tends to increase the income from tourism business.

Moreover, the number of tourists is also an important factor because it is one of the factors that determine the continuity of tourism destination. Some previous researchers propose a concept of how to increase the number of tourists that visit tourism destination. The more number of tourists who visit tourism destination, it is expected to increase the opportunities they will spend money to buy tourism products (Chenini \& Touaiti, 2018). Based on that, number of tourists will have an impact for tourism business income. The regression estimation shows that number of tourists has a positive impact on tourism business income but not significant. The higher number of tourists who visit tourism destination will increase income of local people who did tourism business. The number of tourist will give impact to increase sales of tourism product, and it tends to increase revenue from tourism business (Chenini \& Touaiti, 2018). Seller will receive higher revenue if they could attract the tourist (Cunha et al., 2016). Moreover, consumer or tourist will choose tourism product that has good reputation and image (Mihic \& Culina, 2006; Jee et al., 2019). It tends to increase tourism business income. Based on that, this result is supporting the previous research, although it is not significant. The large number of visitors not necessarily they spend a lot of their money to buy tourism products. Tip for guide is also different between one tourist and other tourists. This tends to be the reason why the effect is not significant.

On the relationship between social media and tourism business, nowadays social media becomes a trend for marketing tools. Many marketers use social media as the way to promotion. Tourism sector such as hospitality industry, travel agency, airlines, and tourism objects use social media to promote their products (Widiastuti \& Susilowardhani, 2016). Social media defines as an application based on internet that builds by conceptual ideology and has benefits such as discussion forum, decision making, connecting company or organization with their partner and consumer, and also as the promotion tools (Kaplan \& Haenlein, 2010). Social media have been used by the tourist to search information about tourism product, thus the stakeholder of tourism business should understand how to manage social media as the tool to reach the potential tourist (Leung et al., 2013). If the local communities at tourism objects are able to use social media, it will increase the number of tourists. Based on that, social media will have an impact on income of tourism business.

Regression estimation result shows that social media has a positive effect on income, but not significant. From the 118 respondents, only 9 respondents have 4 social media, 63 respondents have 3 social media, 17 respondents have 2 social media, and 29 respondents only have 1 social media. Social media has an impact to influences the trends of society and becomes an effective tool for marketing (Alves et al., 2016). If the promotion via social media has been success, it tends to attract tourist to visit tourism destination. Thus, if number of tourists is increasesing it tends to give opportunities they will buy tourism products at the destination and improve the tourism business income. Previous research said that Facebook is the most often used by the people around the world to do communication activities (Bashar et al., 2013). The use of social media affect the potential tourist's trust and also affect their intention to visit tourism destination or to buy some tourism products (Hajli, 2013). In this research, the positive effect is not significant. This is happening because the use of social media by the local communities who did tourism business is not optimal. Some of the respondents only have social media but rarely use it for promotion tools. Because of that condition, the impact which is received by them is not significant.

The results of this research show that effects of social media and number of visitors toward tourism business income are not significant. Based on the depth interview with tourism entrepreneurs in Dieng Plateau, social media owned by them has not been used maximally as a promotion tool. This then to be the reason why the positive effect is not significant. The previous study proved that the usage of social media as a promotion tool has a positive impact on business growth and performance (Singh \& Sinha, 2017). Based on that, the key to gain significant effect from social media on tourism business income is the usage. It would be useless if they have social media but they do not use it as a promotion tool for their tourism business. Therefore, the local government, in this case, is the Tourism Department of Central Java should give a workshop for local tourism entrepreneurs about awareness of social media as a promotion tool for tourism business. Moreover, it is not only building awareness but also provide training on how to use social media as a promotion tool for tourism business. The usage of social media as an appropriate promotion tool is expected to increase the number of visitors and increase tourism business income.

Furthermore, people should manage between their incomes, consumption, and saving in order to enter the economic stable condition, rise their economic status, or at least remain stable until retirement (Luong \& Hebbert, 2009). Local people who did tourism business also need 
to manage their income and household consumption. Income has a positive impact to consumption (Ismail \& Bakar, 2012). Based on that, if someone gets higher income it tends to spend their income and add their household consumption. From 118 respondents, 75 respondents have income IDR 1.000.000 to IDR 5.000.000 per month, 34 respondents have income more than IDR 5.000.000 per month, and 9 respondents have income less than IDR 1.000.000 per month. The result of the second model is income has a significant positive effect on household consumption. This result supports the theory of income changing which is said that increase for income causing consumers to add their consumption with the condition that price is stable (Pindyck, 2009).

Even though, previous research said if family receive higher income will affect to increase their consumption although not significant because they tend to use the income for other important things (Kornrich, 2017). Other than that, other researchers said that people tend to use most of their income to saving (Ismail \& Bakar, 2012). Moreover, there is a differentiation of consumer behavior as an impact on the differentiation of economic classes (Elwell, 2014). The middle class tends to consume only primary goods, while the upper class can consume any goods according to the taste of the consumer. Other researchers also agreed that consumer behavior will be change when someone receives a higher income (Nerman, 2015). Based on that, if local communities receive a higher income from their tourism business it will affect their consumption. They tend to add their household consumption if they receive a higher income.

\section{CONCLUSIONS}

According to the result and discussion, it can be concluded that demographic characteristics such as age and education level have positive and significant impact on tourism business income. Working time also positively significant influence on tourism business income. Even though, the number of tourists and social media have positive effect on tourism business income but not significant. Moreover, tourism business income has positive and significant impact toward household consumption.

Based on the result of this research, the Government should make policies to increase the welfare of local communities in tourism destination area. The Government should encourage the local tourism entrepreneurs to consider age, level of education, and working time in order to increase their tourism business income. One of the business members should have a productive age, have a better education background, and manage their working time so that expected to increase their income. The Government should provide champaign and training on the usage of social media as a promotion tool for tourism business. It is expected to increase the number of visitors and opportunities to spend money on tourism products. Thus will increase the income for tourism entrepreneurs. Moreover, if they get a higher income they will be able to have opportunities to fulfill their needs, hopes, and wants by their level of household consumption. Besides, they should learn to manage their income by making financial accounting so they could spend their income on household consumption wisely and keep the rest for saving or develop their tourism business.

This research conducted limited on the Dieng Plateau area as a tourism object. Further research can develop other tourism areas with the same characteristic to expand research benefits. The analytical tool in this research is only able to analyze one direction and has not been complex in observing the direction of the influence between independent variables toward the dependent variable. It can also be further developed by implementing other data analysis methods such as SEM or PLS. Even though, this research can be used as the fundamental for future research by developing other variables and other data analysis methods on different tourism objects.

\section{REFERENCES}

Agustina, T. S. 2019. Kewirausahaan di Era Revolusi Industri 4.0. Jakarta: Mitra Wacana Media.

Alves, H., Fernandes, C., \& Raposo, M. 2016. Social Media Marketing: A Literature Review and Implications. Psychology and Marketing, 33(12), 1029-1038. https://doi.org/10.1002/mar.20936

Bashar, A., Ahmad, I., \& Wasiq, M. 2013. Effectiveness of Social Media as A Marketing Tool: an Empirical Study. International Journal of Marketing. Financial Services \& Management Research, 1(11), 88-99.

Cette, G., Chang, S., \& Konte, M. 2011. The Decreasing Returns on Working Time: An Empirical Analysis on Panel Country Data. Banque de France Working Paper, (315). https://doi.org/http://dx/ doi.org/10/2139/ssrn.1746857

Chenini, A., \& Touaiti, M. 2018. Building Destination Loyalty Using Tourist Satisfaction and Destination Image: A Holistic Conceptual Framework. Journal of Tourism, Heritage \& Services Marketing, 4(2), 37-43. https://doi.org/10.5281/zenodo.1490491

Chetty, R. 2016. The Association Between Income and Life Expectancy in The United States 2001-2014. JAMA, 16(315), 1750-1766.

Cunha, G. H. M., Oliveira, M. A. C., \& Sosa, W. 2016. Remarks on Fenchel-Moreau conjugate in the setting of consumer theory. EconomiA, 17(2), 176184. https://doi.org/10.1016/j.econ.2016.04.001

Elwell, K. C. 2014. The Distribution of Household Income and the Middle Class. Congressional Research Service, 1-7. 
Figueiredo, L. de, \& Nakabashi, L. 2016. The relative importance of total factor productivity and factors of production in income per worker: Evidence from the Brazilian states. EconomiA, 17(2), 159-175. https://doi.org/10.1016/j.econ.2016.03.005

Gururaja, R. 2015. Impact of Social Media on Tourism and Hospitality. Sastech Technical Journal of RUAS, 2(1), 24-26. Retrieved from http://www. msruas.ac.in/pdf files/Publications/MCJournals/ March2015/4_Rashmi Gururaj.pdf

Hajli, M. N. 2013. A Study of the Impact of Social Media on Consumers. International Journal of Market Research, 56(3), 387-404. https://doi.org/10.2501/ IJMR-2014-025

Haseeb, M., Hussain, H. I., Ślusarczyk, B., \& Jermsittiparsert, K. 2019. Industry 4.0: A Solution towards Technology Challenges of Sustainable Business Performance. Social Sciences, 8(5), 154. https://doi.org/10.3390/socsci8050154

Hsieh, C. M. 2011. Money and happiness: Does age make a difference? Ageing and Society, 31(8), 12891306. https://doi.org/10.1017/S0144686X10001431

Ismail, R., \& Bakar, N. T. A. 2012. The Relationship Between Income, Expenditure, and Household Savings in Peninsular Malaysia. Malaysian Journal of Consumer and Family Economics, 15, 168-189.

Jee, T.-W., Ting, H.-B., \& Alim, M. A. 2019. Community Based Tourism Re-Visit Intention: Tourists' Perspective. International Journal of Business and Society, 20(2), 585-604.

Justus, M., Kawamura, H., \& Kassouf, A. L. 2015. What is the best age to enter the labor market in Brazil today? EconomiA, 16(2), 235-249. https:// doi.org/10.1016/j.econ.2015.03.007

Kaplan, A. M., \& Haenlein, M. 2010. Users of the world, unite! The challenges and opportunities of Social Media. Business Horizons, 53(1), 59-68. https:// doi.org/10.1016/j.bushor.2009.09.003

Karim, Z. 2018. The Impact Of Social Media On Tourism Industry Growth In Bangladesh. International Journal of Economics, Commerce and Management, VI(8), 463-482.

Kornrich, S. 2017. Household Income, Women's Earnings, and Spending on Household Service, 1980-2010. Journal of Marriage and Family, 8(1), $150-165$.

Leung, D., Law, R., Hoof, H. Van, \& Buhalis, D. 2013. Social Media in Tourism and Hospitality: A Literature Review. Journal of Travel \& Tourism Marketing, 30, 3-22. https://doi.org/10.1080/105 48408.2013.750919

Luong, M., \& Hebbert, B.-P. 2009. Age and Earnings. Perspectives Statistic Canada, 1-7.

Mankiw, N. G. 2015. Principles of Macroeconomics.
Canada: Cengage Learning.

Mihic, M., \& Culina, G. 2006. Buying Behavior And Consumption: Social Class Versus Income. Management, 11(2), 77-92.

Monte, P. A. Do. 2017. Public versus private sector : Do workers' behave differently? EconomiA, 18(2), 229 243. https://doi.org/10.1016/j.econ.2017.01.001

Nerman, M. 2015. Household's Income-Generating Activities and Marginal Returns to Labour in Rural Tanzania. Journal of African Economics, 24(3), 367-389.

Pindyck, S. R. 2009. Mikroekonomi Edisi Keenam Jilid 1. Jakarta: Indeks.

Rusliati, E., Mulyaningrum, M., \& Sufyani, M. A. 2018. Development Strategies of Micro Business in Majalengka Regency. Trikonomika, 17(2), 101. https://doi.org/10.23969/trikonomika.v17i2.1050

Sahin, G. G., \& Sengun, G. 2015. The Effects of Social Media on Tourism Marketing: A Study among University Students. Management and Andministrative Sciences Review, 4(5), 772-786.

Singh, T., \& Sinha, R. 2017. The Impact of Social Media on Business Growth and Performance in India. International Journal of Research in Management \& Business Studies, 4(1), 36-40.

Strazdins, L. 2017. Long Hours and Longings: Australian Children's Views of Father's Work and Family Time. Journal Marriage and Family, 79(4), 965-982.

Syah, D. O., \& Rustanto, A. E. 2018. Tourism to Socio Culture and Economy of Community in Panusupan Purbalingga. Trikonomika, 17(1), 14. https://doi. org/10.23969/trikonomika.v17i1.438

Turcinkova, J., \& Stavkova, J. 2012. Does the Attained Level of Education Affect The Income Situation of Households? Procedia -Social and Behavioral Sciences, 55, 1036-1042. https://doi.org/10.1016/j/ sbspro.2012.09.595

Widiastuti, R. D., \& Susilowardhani, E. M. 2016. Virtual Hotel Operator Is It Disruption For Hotel Industry? Jurnal Hospitality Dan Pariwisata, 2(2), 201-215.

Widjaja, A. E., Hery, \& Tarigan, R. E. 2016. Meningkatkan Potensi Pariwisata Danau Toba Melalui Konsep Smart Tourism : Aplikasi dan Tantangannya. Prosiding Seminar Nasional Inovasi Dan Teknologi Informasi SNITI 3, 3, 1-6.

Yoo, C. K., Yoon, D., \& Park, E. 2018. Tourist motivation: an integral approach to destination choices. Tourism Review, 73(2), 169-185. https:// doi.org/10.1108/TR-04-2017-0085

Zivkovic, R., Gajic, J., \& Brdar, I. 2014. The Impact of Social Media on Tourism. Proceedings of the $1 \mathrm{st}$ International Scientific Conference - Sinteza 2014, (November), 758-761. https://doi.org/10.15308/ sinteza-2014-758-761 
Vol. 19, No. 1, June 2020

Table 1. Respondent Characteristic

\begin{tabular}{|c|c|c|c|}
\hline & Characteristic & Total & Percentage \\
\hline \multirow[t]{2}{*}{ Gender } & Male & 41 & $35 \%$ \\
\hline & Female & 77 & $65 \%$ \\
\hline \multirow[t]{7}{*}{ Age } & $18-27$ yo & 24 & $20 \%$ \\
\hline & $28-37$ yo & 19 & $16 \%$ \\
\hline & $38-47$ yo & 35 & $30 \%$ \\
\hline & $48-57$ yo & 26 & $22 \%$ \\
\hline & $58-67$ yo & 12 & $10 \%$ \\
\hline & $68-77$ yo & 1 & $1 \%$ \\
\hline & $78-87$ yo & 1 & $1 \%$ \\
\hline \multirow[t]{5}{*}{ Education } & Without education background & 2 & $2 \%$ \\
\hline & Elementary School & 34 & $29 \%$ \\
\hline & Junior High School & 44 & $37 \%$ \\
\hline & Senior High School & 31 & $26 \%$ \\
\hline & College & 7 & $6 \%$ \\
\hline Tourism & Food stalls & 70 & $59 \%$ \\
\hline \multirow[t]{4}{*}{ Business } & Souvenir shop & 35 & $30 \%$ \\
\hline & Restaurant & 1 & $1 \%$ \\
\hline & Tour Guide & 8 & $7 \%$ \\
\hline & Homestay & 4 & $3 \%$ \\
\hline Social & 4 units & 9 & $8 \%$ \\
\hline \multirow[t]{3}{*}{ Media } & 3 units & 63 & $53 \%$ \\
\hline & 2 units & 17 & $14 \%$ \\
\hline & 1 unit & 29 & $25 \%$ \\
\hline \multirow[t]{3}{*}{ Income } & $<$ IDR 1.000 .000 & 9 & $7,6 \%$ \\
\hline & IDR 1.000 .000 - IDR 5.000 .000 & 75 & $63,6 \%$ \\
\hline & $>$ IDR 5.000 .000 & 34 & $28,8 \%$ \\
\hline
\end{tabular}

Source: primary data 2019
Table 2. Mean

\begin{tabular}{llll}
\hline \multicolumn{1}{c}{ Variables } & \multicolumn{1}{c}{ Per month } & \multicolumn{1}{c}{ Per week } & \multicolumn{1}{c}{ Per day } \\
\hline Working Time & 227 hours & 57 hours & 8 hours \\
Visitors & 192 visitors & 48 visitors & 7 visitors \\
Income & IDR 3.999.153 & IDR 999.788 & IDR 142.827 \\
Household & IDR 2.540.720 & IDR 635.180 & IDR 90.740 \\
Consumption & & & \\
\hline \multicolumn{2}{l}{ Source: primary data 2019 }
\end{tabular}

Table 3. First Model Regression Result

\begin{tabular}{|c|c|c|c|c|}
\hline \multirow[b]{2}{*}{ Model } & \multicolumn{2}{|c|}{ Unstandardized Coefficients } & \multirow[b]{2}{*}{$\mathrm{t}$} & \multirow[b]{2}{*}{ Sig. } \\
\hline & B & Std. Error & & \\
\hline Constant & -2706781.995 & 1085691.281 & -2.493 & $0.014 * *$ \\
\hline $\mathrm{AG}$ & 48386.977 & 14994.241 & 3.227 & $0.002 * * *$ \\
\hline ED & 126563.564 & 66814.359 & 1.894 & $0.061 *$ \\
\hline WT & 15795.775 & 7404.329 & 2.133 & $0.035 * *$ \\
\hline TR & 1983.450 & 3747.158 & 0.529 & 0.598 \\
\hline SM & 369516.240 & 224873.989 & 1.643 & 0.103 \\
\hline
\end{tabular}

Note: * significant of $\alpha(10 \%), * *$ significant of $\alpha(5 \%), * * *$ significant of $\alpha(1 \%)$

Source: primary data 2019

Table 4. Second Model Regression Result

\begin{tabular}{|c|c|c|c|c|}
\hline \multirow[b]{2}{*}{ Model } & \multicolumn{2}{|c|}{ Unstandardized Coefficients } & \multirow[b]{2}{*}{$\mathrm{t}$} & \multirow[b]{2}{*}{ Sig. } \\
\hline & $\mathrm{B}$ & Std. Error & & \\
\hline Constant & 978372.419 & 169366.515 & 5.777 & $0.000 * * *$ \\
\hline $\mathrm{INC}$ & 0.391 & 0.035 & 11.287 & $0.000 * * *$ \\
\hline
\end{tabular}

Note: *** significant of $\alpha(1 \%)$

Source: primary data 2019 